\title{
Betonarme Kolonların Yerdeğiştirme Kapasitesi Tahmini için Analitik Çalış̧ma
}

\section{Analytical Study for Estimation of Displacement Capacity of Reinforced Concrete Columns}

\author{
Dr. Sinan Cansız ${ }^{1}$ (D)

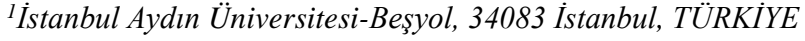

Başvuru/Received: 24/01/2021

Kabul / Accepted: 09/04/2021

Çevrimiçi Basım / Published Online: 23/05/2021

Son Versiyon/Final Version: 18/06/2021

\section{Öz}

Betonarme yapıların davranışında süneklik talebinin belirlenmesinde en önemli eleman olarak kolonlar önce çıkmaktadır. Betonarme kolonların davranışını etkileyen başlıca parametreler; eksenel yük seviyesi, kesme açıklığı, boyuna donatı yüzdesi ve enine donatı yüzdesi olarak sıralanabilir. Bu çalışma kapsamında Seismo-Struct programında modellenmiş çeşitli özelliklere sahip betonarme kolonların sismik analizi yapılmıştır. Analitik sonuçlar ile deneysel sonuçlar karşılaştırılarak analitik modeller doğrulanmıștır. Analitik modellerin sonuçları incelendiğinde betonarme kolonların kalıcı dönme oranının deprem veya yükleme sonrası yapıda oluşan hasarın nitelendirilmesinde kullanılabileceği görülmektedir. Ayrıca FEMA356 yönetmeliğinde betonarme kolonların kalıcı dönme oranına göre performans seviyesi tanımlanmaktadır. Bu çalışma sonucunda betonarme kolonların son limit durumundaki yerdeğiştirme kapasitesini ve kalıcı dönme oranını hesaplayan analitik bağıntı önerilmektedir.

\section{Anahtar Kelimeler}

"Kolon, Betonarme, Yerdeğiștirme Kapasitesi, Sismik Analiz"

\begin{abstract}
Reinforced concrete columns are the most important structural elements that determine the ductility of the structures. The main parameters affecting the behavior of reinforced concrete columns are axial load level, shear span, percent of longitudinal reinforcement and percent of transverse reinforcement. In the context of this study, seismic analysis of reinforced concrete columns with various features modeled in the Seismo-Struct program was performed. Analytical models were verified by comparing the analytical results with the experimental results. When the results of analytical models are examined, it can be seen that the residual drift ratio of reinforced concrete columns can be used to characterize the damage occurred in the structure after earthquake or loading. In addition, the performance level of the reinforced concrete columns according to the residual drift ratio is defined in FEMA356. As a result of this study, the analytical equation that calculates the displacement capacity of the reinforced concrete columns and residual drift ratio of the reinforced concrete columns at the ultimate displacement limit is proposed.
\end{abstract}

Key Words

"Column, Reinforced Concrete, Displacement Capacity, Seismic Analysis" 


\section{Giriş}

Betonarme yapıların tasarımında şekil değiştirme esaslı yaklaşımlar ile kuvvet esaslı yaklaşımlar kullanılmaktadır. Deprem Bölgelerinde Yapılacak Binalar Hakkında Yönetmeliğe (2007) göre betonarme yapıların mevcut performansının tespitinde şekil değiştirme esaslı yaklaşımlar kullanılmaktadır. 2018 yılında yayımlanan Türkiye Bina Deprem Yönetmeliği ile şekil değiştirme esaslı yaklaşımlar ile yeni binaların tasarımına yer verilmiştir. 1990'lı yıllarda gerçekleşen Kobe ve Northridge depremleri sonrası kuvvet esaslı yaklaşımlar ile tasarlanmış yapıların deprem sonrası kullanımının uygun olmaması sebebiyle ekonomik kayıplara sebep olmuştur. Ardından performansa dayalı tasarım yaklaşımı benimsenerek hedef performansa bağlı yapıların tasarımına ağılık verilmiştir. Performansa dayalı tasarım veya şekil değiştirme esaslı yaklaşımların en önemli parametrelerinden birisi tasarımda şekil değiştirme limitlerinin kullanılması olarak öne çıkmaktadır. Belirli değere kadar şekil değiştirme tanımlanan yapılarda deprem sonrası belirli hasarın oluşmasına izin verilmektedir.

Betonarme kolonların hasar durumu üzerine birçok araştırmacı çalışma yapmıştır. Meral'in (2019) yapılan çalışmasında 2007 deprem yönetmeliğine göre tasarlanmış 4 ve 7 katlı binalarda, kısa kolon etkilerini araştırmıştır. Çalışma sonucunda 4 katlı yapılarda kısa kolon sonucu hasar durumu \%40 seviyesinde iken, 7 katlı kısa kolonlu binalarda hasar seviyesi \%60 mertebesinde tespit edilmiştir.

Aykaç vd. 2014 yılında yapılan çalışmalarında dikdörtgen kesite sahip betonarme kolonların yaklaşık hesabı için basit bir formulasyon önermiş̧ir. Eksenel yük seviyesi yüksek kolonlarda bile doğru sonuçlar verebilen formulasyon ile yaklaşık \%15 hata payı ile betonarme kolonların donatısı hesaplanabilmektedir.

Forougi ve Yüksel (2019) Türkiye Bina Deprem Yönetmeliğine (TBDY-2018) göre betonarme kolonlar şekil değiştirme hasar sınırları üzerine analitik çalışma yapmıştır. Bu bağlamda farklı donatı ve en kesit özelliklerine sahip betonarme kolonların analitik olarak şekil değiştirme hasar sınırları farklı performans durumlarına karşıllık gelecek şekilde hesaplanmıştır. Çalışmanın sonucunda betonarme kolonların tasarımını etkileyen parametrelerin şekil değiştirme hasar sınırlarına etkisi belirlenmiştir.

Bae ve Bayrak (2008) tarafından hazırlanan makale çalışmasında, yeni bir plastik mafsal modeli hazırlanmıştır. Önerilen plastik mafsal modeli eksenel yükün etkisini dikkate alarak, mevcut plastik mafsal modelleriyle karşılaştırılmıştır. Deneysel ve literatürdeki verilere göre önerilen plastik mafsal modelinin uygun sonuçlar verdiği görülmüştür.

El-Bahy, Kunnath, Stone ve Taylor (1997) tarafından yapılan çalışmada, farklı yükleme durumlarına sahip 12 betonarme kolonun sismik analizi yapılmıştır. Elde edilen sonuçlara göre yükleme şekillerinin betonarme kolonların davranışına nasıl etki ettiği görülmüş ve yeni bir hasar modeli hazırlanmıştır.

Azizinamini, Corley ve Johal (1992) tarafından yapılan çalışmada farklı eksenel yük seviyesi ve farklı enine donatı oranına sahip 12 betonarme kolonun sismik yükler altında deneysel analizi yapılmışıı. Çalışma kapsamında araştırılan parametreler; eksenel yük seviyesi ve enine donatı detayları yer almaktadır. Çalışma sonucunda yeni enine donatı detayları tanımlanmış ve test edilerek doğruluğu kanıtlanmıştır.

Elwood ve Moehle tarafından yapılan çalışmada betonarme kolonların yerdeğiştirme bileşenleri ile FEMA356 yönetmeliğinde bulunan iskelet eğrisi metodunu kullanarak betonarme kolonların dönme kapasitesi üzerine inceleme yapılmıştır.

Lehmann ve Moehle (2000) tarafından hazırlanan çalışmada, hasar indekslerinin tekrarlı yükler altında sonuçları irdelenmiştir. Çalışma neticesinde deneysel sonuçlar kullanılarak yeni bir hasar modeli geliştirilmiştir. Analitik araştırmada, deneysel sonuçlar kullanılarak eleman hasarını değerlendirmek için mühendislik parametrelerini sayısal olarak değerlendirme yöntemleri geliştirilmiştir. Araştırma sonuçları betonarme köprü kolonları için performansa dayalı yaklaşımı geliştirmek amacıyla kullanılmıştır.

Öztürk (2003) tarafından yapılan tez çalışmasında betonarme yapıların deprem yüklerine karşı sismik dönme taleplerinin değerlendirilmesi için basit bir prosedür önerilmiştir. Öztürk tarafından 2007 yılında sunulan çalışmasında da önceki çalışmasının devamı olarak, sismik bölgelerdeki yapıların dönme talepleri incelenmiştir.

Ülkemizde deprem sonrası kullanılan önemli sayıda yapı stoğu bulunmaktadır. Bu yapıların mevcut performansının tespiti için sismik yönetmeliklerde tanımlanan yöntemler birçok araştırmacı tarafından hazırlanan deney setleri ile araştırılmıştır. Bu çalışmalarda genellikle tasarıma etki eden sınırlı parametreler sınırlı aralıklarda incelenmiştir. Betonarme kolona etki eden parametrelerin oluşabilecek değer aralıklarının tamamında deney yapımının maliyetli ve süre alması sebebiyle performansa dayalı tasarımda istenen seviyede ilerleme kaydedilememiştir. Betonarmenin davranışını anlayabilmek için en önemli gerekliliklerden birisi aynı deney seti üzerinde birçok parametrenin incelenmesidir. Deneysel olarak yapılması zor durumu analitik olarak değerlendirmek hem maliyetsiz hem de daha az zamanla gerçekleştirilebilmektedir. Literatürdeki önceki çalışmalar incelendiğinde genellikle belli parametreler altında betonarme kolonun az sayıda üretilen kolon numunelerinin davranışı incelenmiştir. Ayrıca deneyde incelenen kolonların sayısı ve incelenen parametrelerin az sayıda olması sebebiyle betonarme kolonların davranışına tam etkisi detaylıca incelenememiştir. Bu çalışmanın diğer çalışmalardan farkı ise betonarme kolon tasarımına etki eden en önemli parametreler geniş değişken aralığında 
incelenerek kolonların tümden davranışı incelenmiştir. Çalışma kapsamında üretilen analitik model deneysel çalışmalar ile doğrulanarak, çalışmanın güvenilirliği arttırılmıştır.

$\mathrm{Bu}$ çalışma kapsamında betonarme kolonların tasarım parametreleri dikkate alınarak hazırlanmış 16 adet betonarme kolonun SeismoStruct programı ile sismik analizi yapılmıştır. Analizi yapılan kolonlar seçilirken TBDY-2018'e göre yapılacak en büyük ve en küçük parametreler seçilerek en üst ve en alt kapasite oranları belirlenmiştir.

\section{Analitik Modeller}

Bu çalışmada analizi yapılan 16 adet betonarme kolonun seçiminde kullanılan TBDY'e göre sınır değer aralıkları Tablo 1'de gösterilmektedir.

Tablo 1. TBDY-2018'e göre sınır değerler

\begin{tabular}{ccc}
\hline Parametre & Minimum & Maksimum \\
\hline Eksenel yük seviyesi & 0.1 & 0.4 \\
Boyuna donatı yüzdesi & 0.01 & 0.04 \\
\hline
\end{tabular}

Kesme açıklığı için TBDY'de belirtilen sınır değer olmaması sebebiyle, kesme açıklı̆̆ının etkili derinliğe oranı (a/d) 3-10 arası değerler seçilmiş̧ir. Betonarme kolonların seçiminde eksenel yük seviyesi için TBDY-2018'de tanımlanan üst ve alt sınır değerleri seçilmiştir. Benzer şekilde TBDY-2018'de boyuna donatı yüzdesi içinde üst ve alt sınır değerleri seçilerek limit durumlar araştırılmıştır. Enine donatı yüzdesi için ise betonarme yapıların tasarımında sıklıkla kullanılan $50 \mathrm{~mm}-100 \mathrm{~mm}$ etriye aralıklarına karşılık gelen değerler seçilmiştir.

Çalışmada kullanılan analitik olarak modellenmiş kolonların isimlendirilmesinde kullanılan kısaltmalar Şekil 1'de gösterilmiştir.

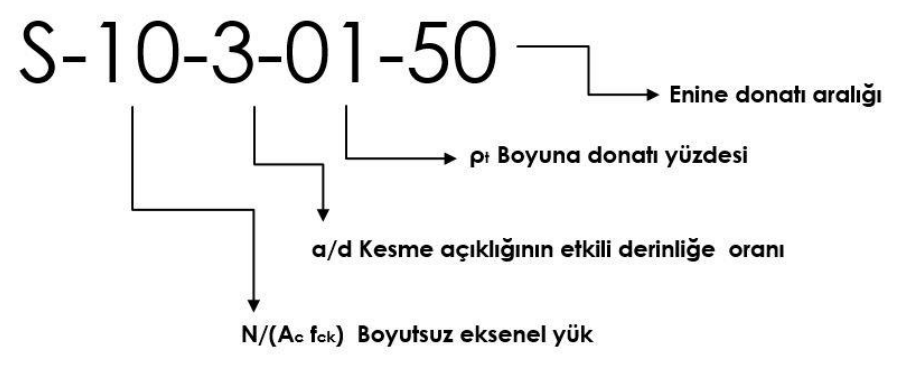

Şekil 1. Bu çalışmada kullanılan kısaltmalar

Bu çalışmada seçilen kolonlar ve özellikleri Tablo 2'de gösterilmiştir.

Tablo 2. Kolonlara ait özellikler

$\begin{array}{ccccc}\text { Kolon Ad } & \text { N/A } \mathbf{A}_{\mathbf{c k}} & \mathbf{a} / \mathbf{d} & \boldsymbol{\rho t} & \mathbf{S}(\mathbf{m m}) \\ \text { S-10-3-01-50 } & 0.1 & 3 & 0.01 & 50 \\ \text { S-10-3-01-100 } & 0.1 & 3 & 0.01 & 100 \\ \text { S-10-3-04-50 } & 0.1 & 3 & 0.04 & 50 \\ \text { S-10-3-04-100 } & 0.1 & 3 & 0.04 & 100 \\ \text { S-10-10-04-50 } & 0.1 & 10 & 0.04 & 50 \\ \text { S-10-10-04-100 } & 0.1 & 10 & 0.04 & 100 \\ \text { S-10-10-01-50 } & 0.1 & 10 & 0.01 & 50 \\ \text { S-10-10-01-100 } & 0.1 & 10 & 0.01 & 100 \\ \text { S-40-3-01-50 } & 0.4 & 3 & 0.01 & 50 \\ \text { S-40-3-01-100 } & 0.4 & 3 & 0.01 & 100 \\ \text { S-40-3-04-50 } & 0.4 & 3 & 0.04 & 50 \\ \text { S-40-3-04-100 } & 0.4 & 3 & 0.04 & 100\end{array}$


Tablo 2 (devam). Kolonlara ait özellikler

$\begin{array}{ccccc}\text { Kolon Adı } & \text { N/A } \mathbf{A}_{\mathbf{c}} \mathbf{c k} & \mathbf{a} / \mathbf{d} & \boldsymbol{\rho t}_{\mathbf{t}} & \mathbf{S}(\mathbf{m m}) \\ \text { S-40-10-04-50 } & 0.4 & 10 & 0.04 & 50 \\ \text { S-40-10-04-100 } & 0.4 & 10 & 0.04 & 100 \\ \text { S-40-10-01-50 } & 0.4 & 10 & 0.01 & 50 \\ \text { S-40-10-01-100 } & 0.4 & 10 & 0.01 & 100\end{array}$

Burada; $\mathrm{N}$ eksenel yükü, $\mathrm{A}_{\mathrm{c}}$ kesit alanını, $\mathrm{f}_{\mathrm{ck}}$ beton basınç dayanımını, a kesme açıklığını, d etkili yüksekliği, $\rho_{\mathrm{t}}$ boyuna donatı yüzdesini ve s etriye aralığını göstermektedir.

Tüm analitik modellerde C30/S420 malzemesi ile $\phi 8$ etriye kullanılmıştır. Boyuna donatı için ise; boyuna donatı yüzdesi 0.04 olan kolonlarda 20\$20, boyuna donatı yüzdesi 0.01 olan kolonlarda ise $8 \phi 16$ simetrik düzen kullanılmıştır. Çalışma kapsamında üretilen analitik modeller $400 \mathrm{~mm}$ / 400 mm en kesite sahip kare kolon seçilmiştir. Kolonların şematik en kesiti ve yükleme düzeni Şekil 2'de gösterilmektedir.

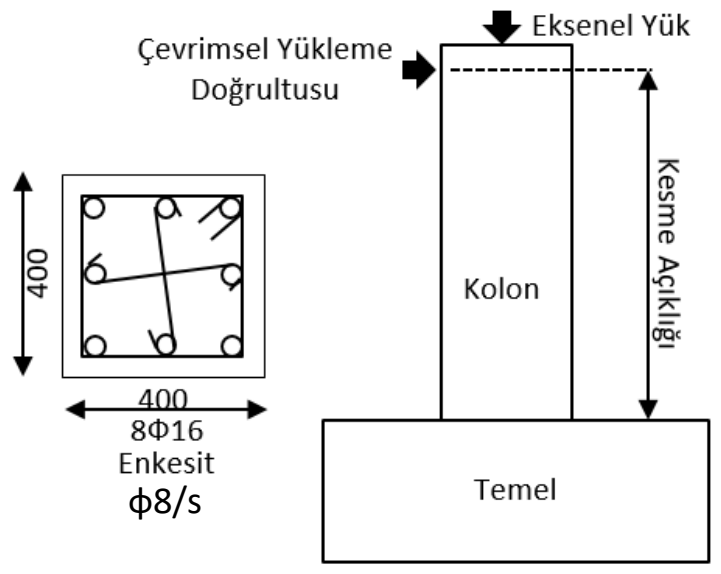

Şekil 2. Şematik kesit ve yükleme düzeni

Tüm kolonlara benzer şematik yükleme profili uygulanmıştır. Tüm kolonlara uygulanan yükleme profili Şekil 3'de gösterilmektedir. Yükleme profilinde akma yer değiştirmesinin artan katları olarak, $0.5 \mu-1 \mu-1.5 \mu-2 \mu-3 \mu-4 \mu-\ldots$ n $\mu$ şeklinde uygulanmıştır.

Tüm kolonların akma yerdeğiştirmesi; Seismo-Struct programında monotonik yükleme altında tespit edilmiştir. Yükleme hızı olarak tüm modellerde saniyede $0.1 \mathrm{~mm}$ artacak şekilde uygulanmıştır.

\subsection{Bilgisayar Programında Modelleme}

Çalışma kapsamında üretilen analitik modeller Seismo-Struct programı kullanılarak analiz edilmiştir. Oluşturulan modellerin doğruluğu için literatürde kullanılan 3 deneysel veri kullanılmıştır. Bu amaçla PEER veritabanında seçilen deneysel kolonlar ve özellikleri Tablo 3'de verilmiştir. Özellikleri gösterilen kolonların analitik modelleri Seismo-Struct programında aynı malzeme dayanımlarına sahip olacak şekilde modellenmiştir. Sargıl1-sargısız beton için Mander modeli (Mander vd. 1988) ve donatı çeliği için Menegetto-Pinto modeli seçilerek Seismo-Struct programında malzeme özelliklerinde tanımlanmıştır. Plastik mafsal kabulünde ise otomatik değer kabul edilerek, programca her çevrimde hesaplanan plastik mafsal boyu dikkate alınmıştır.

Tablo 3. Deneysel kolonlara ait özellikler

\begin{tabular}{ccccc}
\hline Kolon Ad1 & N/A $\mathrm{A}_{\mathrm{c}} \mathrm{f}_{\mathrm{c}}$ & $\mathrm{a} / \mathrm{d}$ & $\rho_{\mathrm{t}}$ & $\rho_{\mathrm{h}}$ \\
\hline Soesianawati vd. 1986 No:1 & 0.1 & 4.26 & 0.015 & 0.002 \\
Saatcioglu ve Grira 1999, BG-2 & 0.42 & 5.20 & 0.019 & 0.005 \\
Azizinamini vd. 1988, NC-2 & 0.2 & 3.43 & 0.019 & 0.005 \\
\hline
\end{tabular}

Burada; $N$ eksenel yükü, $A_{c}$ kesit alanını, $\mathrm{f}_{\mathrm{c}}$ beton basınç dayanımını, a kesme açıklığını, $\mathrm{d}$ etkili yüksekliği, $\rho_{\mathrm{t}}$ boyuna donatı yüzdesini ve $\rho_{\mathrm{h}}$ enine donatı yüzdesini (TBDY) ifade etmektedir 
Tablo 3'de verilen kolonlar Seismo-Struct programı kullanılarak modellenmiştir. Deneysel veriler ile program sonucunda elde edilen analitik sonuçlar yük-yerdeğiştirme grafikleri üzerinde karşılaştırılarak Şekil 3-5'de gösterilmiştir.

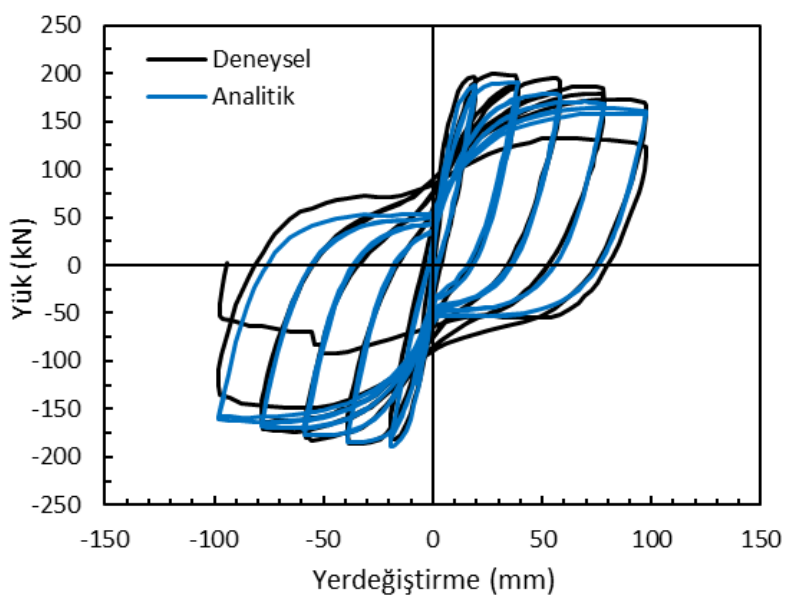

Şekil 3. Soesianawati vd. 1986 No:1 kolonu için deneysel ve analitik sonuçların karşılaş̧ırılması

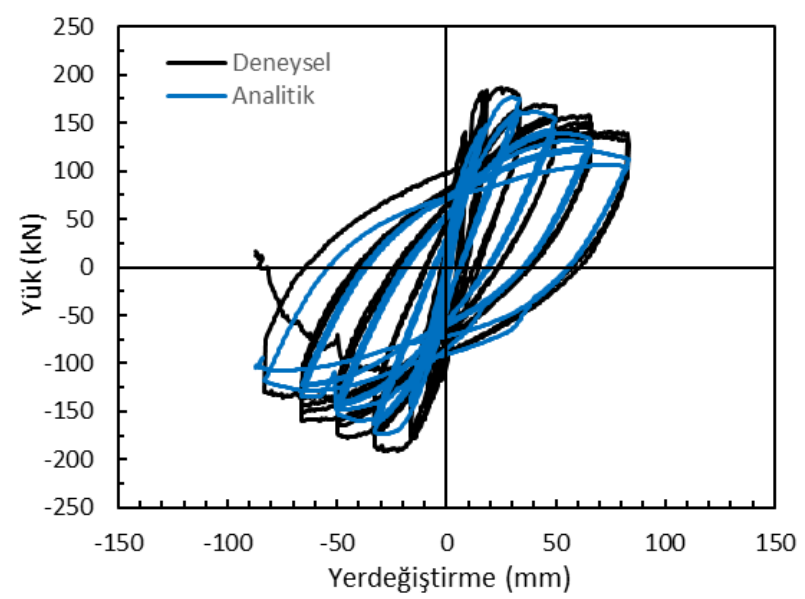

Şekil 1. Saatcioglu ve Grira 1999, BG-2 kolonu için deneysel ve analitik sonuçların karşılaştırılması

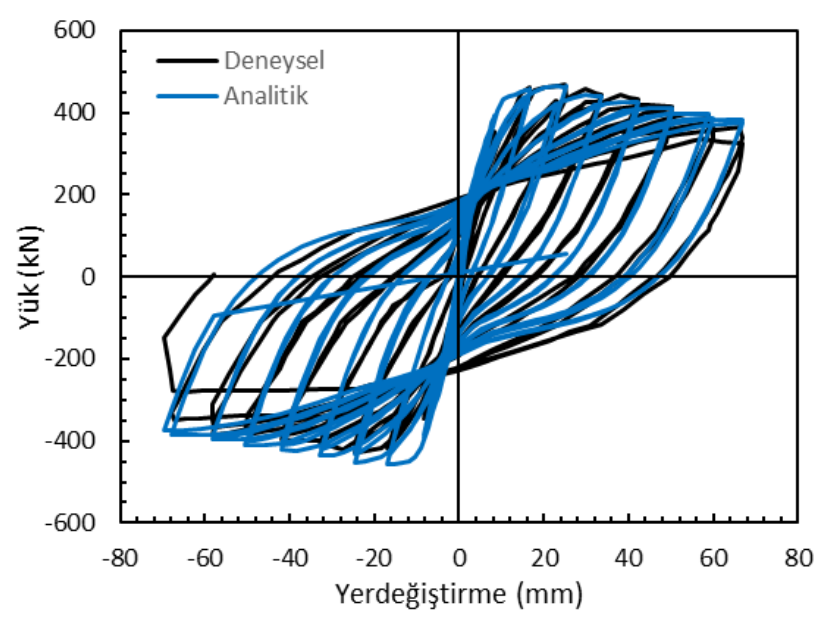

Şekil 2. Azizinamini vd. 1988, NC-2 kolonu için deneysel ve analitik sonuçların karşılaştırılması Analitik sonuçlar ve deneysel sonuçların sayısal olarak karşılaştırılması Tablo 4'de sunulmaktadır. 
Tablo 4. Deneysel-Analitik sonuçların karşılaştııılması

\begin{tabular}{|c|c|c|c|c|c|c|c|c|c|}
\hline \multirow{2}{*}{ Kolon Adı } & \multicolumn{3}{|c|}{ Akma Yerdeğiştirmesi (mm) } & \multicolumn{3}{|c|}{ Yük (kN) } & \multicolumn{3}{|c|}{ Süneklik } \\
\hline & $\Delta_{y, \text { den. }}$ & $\Delta_{\mathrm{y}, \text { anl. }}$ & Hata $(\%)$ & $\mathrm{P}_{\text {maks,den. }}$ & $\mathrm{P}_{\text {maks,anl. }}$ & Hata $(\%)$ & $\mu_{\text {den. }}$ & $\mu_{\text {anl. }}$ & Hata $(\%)$ \\
\hline Soesianawati vd. 1986 No:1 & 21 & 19 & -9.25 & 201 & 191 & -4.90 & 4.76 & 5.26 & +10.50 \\
\hline Saatcioglu ve Grira 1999, BG-2 & 17 & 19 & +11.76 & 187 & 176 & -3.70 & 4.70 & 4.21 & -10.42 \\
\hline Azizinamini vd. 1988, NC-2 & 16 & 14 & +12.50 & 458 & 465 & +1.50 & 4.37 & 5.00 & +14.41 \\
\hline
\end{tabular}

Analitik sonuçlar ile deneysel sonuçlar karşılaştırıldığında Seismo-Struct programına ait sonuçların deneysel sonuçlara çok yakın olduğu görülmüştür. Tablo 4 incelendiğinde maksimum yükü analitik modellemede oldukça iyi tahmin ederken, akma yer değiştirmesi ve süneklik kapasitesini ortalama \% 12 hatalı tespit etmiştir. Ayrıca çalışma kapsamında incelenen kalıcı dönme oranını ve yerdeğiştirme kapasitesinin gerçek değere çok yakın olduğu gözlemlenmiştir. Program içerisinde kalıcı yerdeğiştirme değerini etkileyen plastik mafsal boyunun doğru modellenmesi ile gerçeğe yakın sonuçlar elde edilmiştir. Bu bağlamda modellenen kolonların program görüntüleri Şekil 6'da gösterilmektedir.

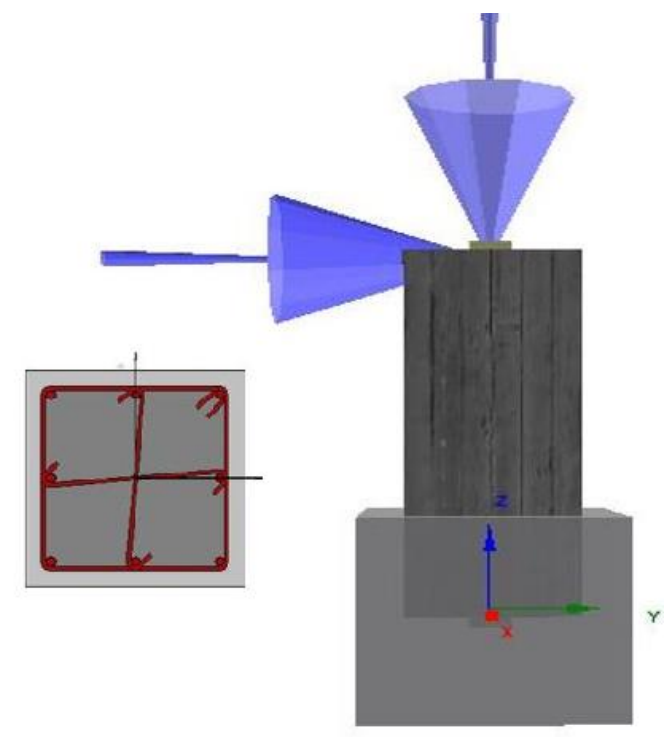

Şekil 3. Modellenen kolonlara ait görüntüler

\section{Analitik Modellere ait Sonuçlar}

EUROCODE-8 yönetmeliğine göre betonarme kolonların göçme öncesi performans düzeyi, yatay yük taşıma kapasitesinde \%20 azalmaya karşılık gelen yerdeğiştirme değeri olarak tanımlanmıştır. Benzer şekilde FEMA356 Amerikan standardında ise betonarme kolonların boyutsuz eksenel yük seviyesi ile boyutsuz kesme kuvvetine bağlı belirlenen plastik dönme oranı ile tanımlanmıştır. Türkiye Bina Deprem Yönetmeliğinde (2018) ise malzeme birim şekil değiştirme değerlerine göre belirlenen plastik dönme kapasitesi ile tanımlanmıştır. Önceki deneysel çalışmalar incelendiğinde betonarme kolonlarda yatay yük taşıma kapasitesinde \%20 azalma meydana getiren yerdeğiştirme altında ağır hasar oluştuğu görülmüş̧ür. Dünyada yaygın olarak kullanılan sismik yönetmelikler bu hasar altında yapının göçme öncesi performans seviyesinde olduğunu tanımlamaktadır. Özetle ulusal ve uluslararası kullanılan sismik yönetmeliklerde farklı parametrelere göre hesap yapan farklı bağıntılar ile aynı nokta tespit edilmeye çalışılmaktadır.

Seismo-Struct programı ile yapılan sismik analiz sonucu kolonların yük-yerdeğiştirme ilişkileri Şekil 7-22'de sırasıyla gösterilmiştir. Bu amaçla tüm kolonların yük-yerdeğiştirme ilişkileri üzerinde maksimum yatay kuvvet (kırmızı çizgi) ve $0.8 \mathrm{~V}_{\text {maks }}$ değeri (mavi çizgi) işaretlenmiştir.

Çalışma kapsamında tüm analitik modellerin; yerdeğiştirme kapasitesi $\left(\Delta_{\mathrm{u}}\right)$, yerdeğiştirme kapasitesi altında oluşan kalıcı yerdeğiş̧irme $\left(\Delta_{\mathrm{k}}\right)$, maksimum dönme oranı $\left(\theta_{\mathrm{u}}\right)$ ve yerdeğiştirme kapasitesi altında hesaplanan kalıcı dönme oranı $\left(\theta_{\mathrm{k}}\right)$ belirlenmiştir. Hesaplanan bu paramtreler her şekil üzerinde işaretlenerek gösterilmiştir. Ayrıca grafik üzerinde birincil düşey eksen kesme kuvvetini, ikincil düşey eksen FEMA356'da tanımlanan boyutsuz kesme kuvvetini, birincil yatay eksen yatay yerdeğiştirmeyi ve ikincil yatay eksen kolon numunesi tepe yer değiştirmesine göre oluşan yüzdece dönmeyi göstermektedir. 
$\%$ Dönme

$\begin{array}{lllllllllllllllllllll}-9 & -8 & -7 & -6 & -6 & -5 & -4 & -3 & -2 & -1 & 0 & 1 & 2 & 3 & 4 & 5 & 6 & 6 & 7 & 8 & 9\end{array}$

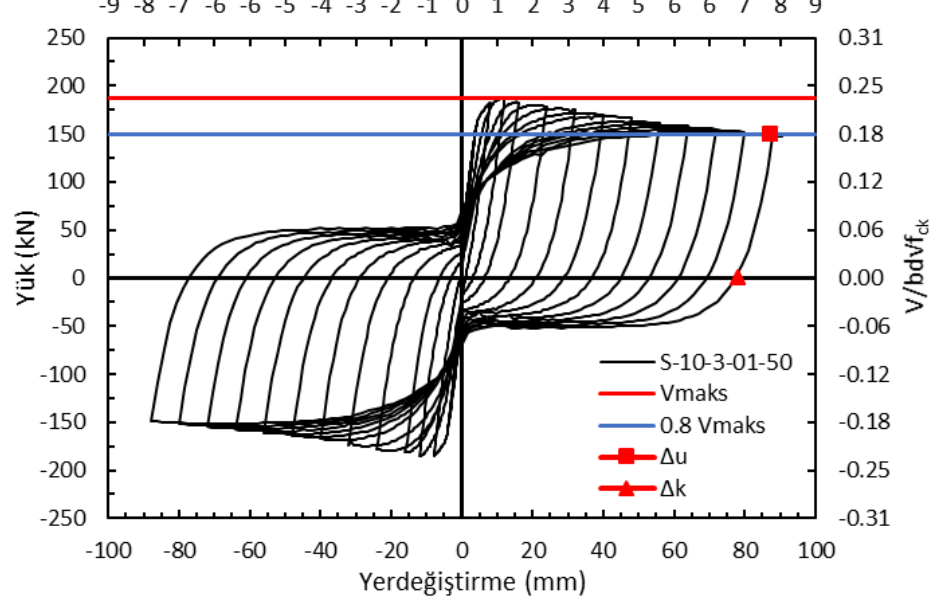

Şekil 4. S10-3-01-50 kolonuna ait yük-yerdeğiştirme ilişkisi

\% Dönme

$\begin{array}{lllllllllllllllllllll}9 & -8 & -7 & -6 & -6 & -5 & -4 & -3 & -2 & -1 & 0 & 1 & 2 & 3 & 4 & 5 & 6 & 6 & 7 & 8 & 9\end{array}$

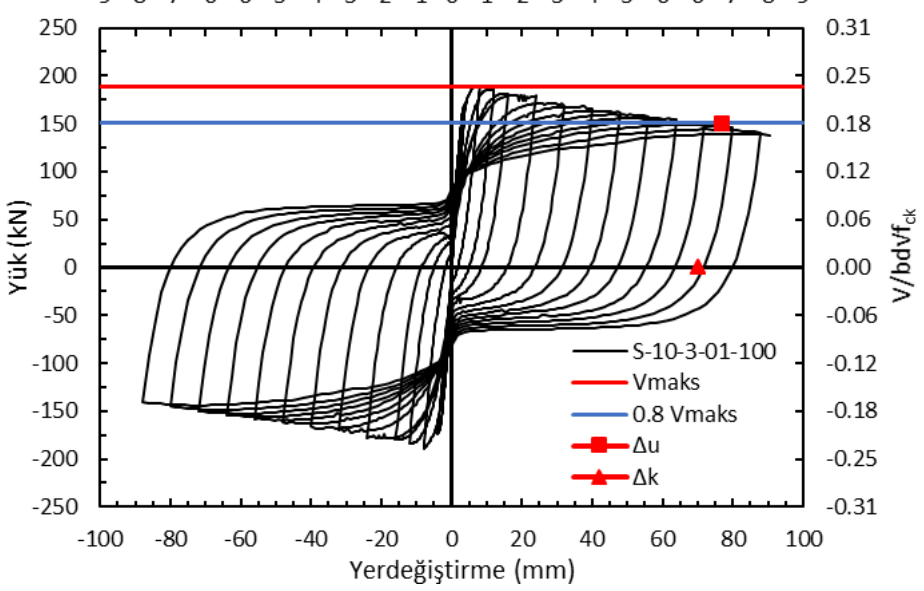

Şekil 8. S10-3-01-100 kolonuna ait yük-yerdeğiştirme ilişkisi

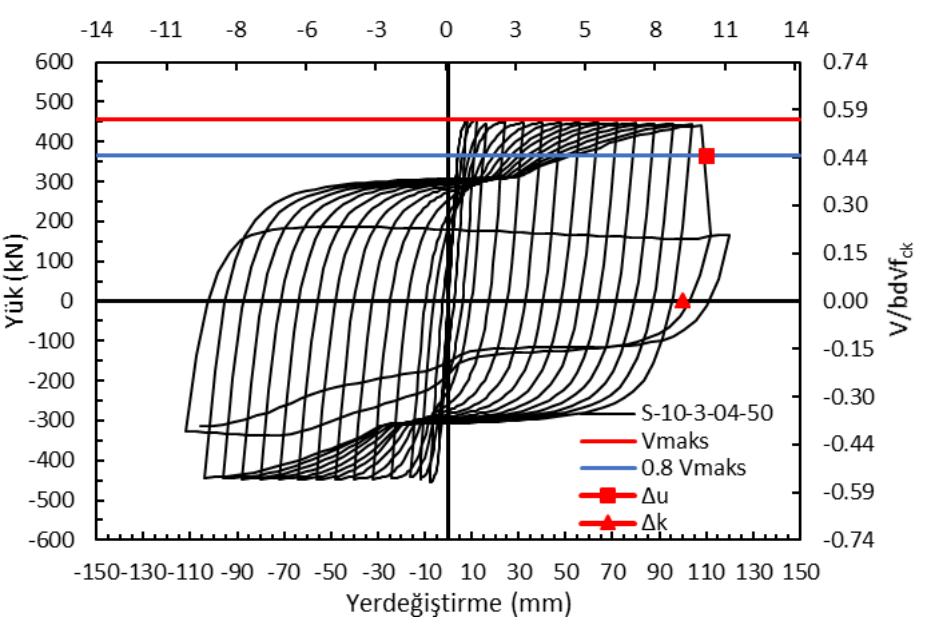

Şekil 9. S10-3-04-50 kolonuna ait yük-yerdeğiştirme ilişkisi 


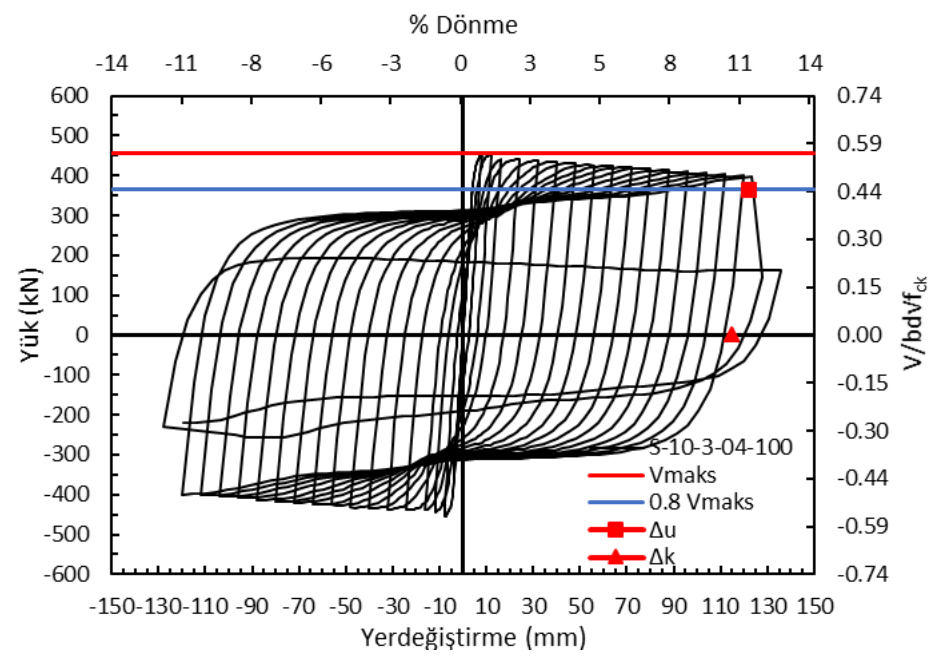

Şekil 10. S10-3-04-100 kolonuna ait yük-yerdeğiştirme ilişkisi

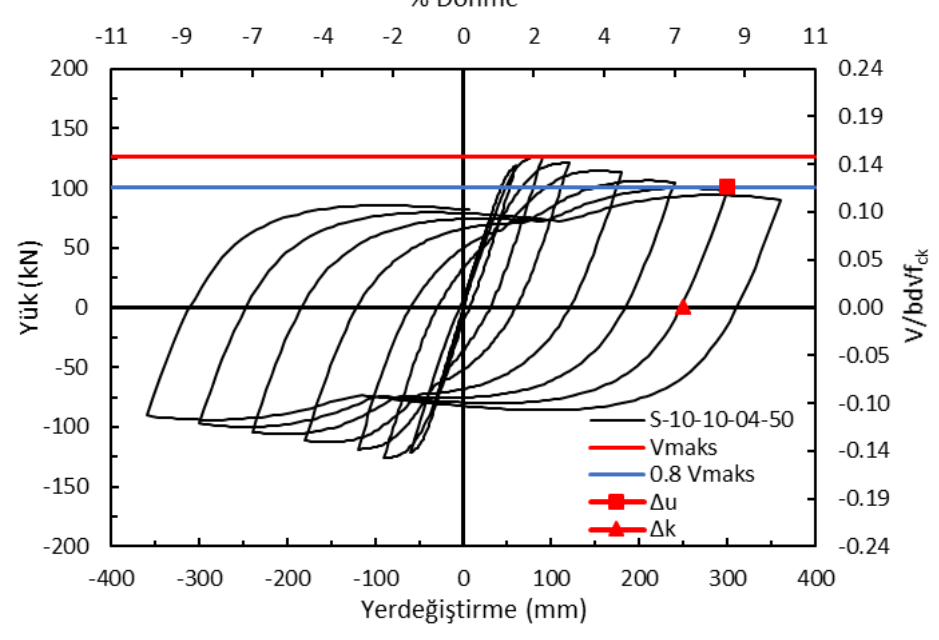

Şekil 11. S10-10-04-50 kolonuna ait yük-yerdeğiştirme ilişkisi

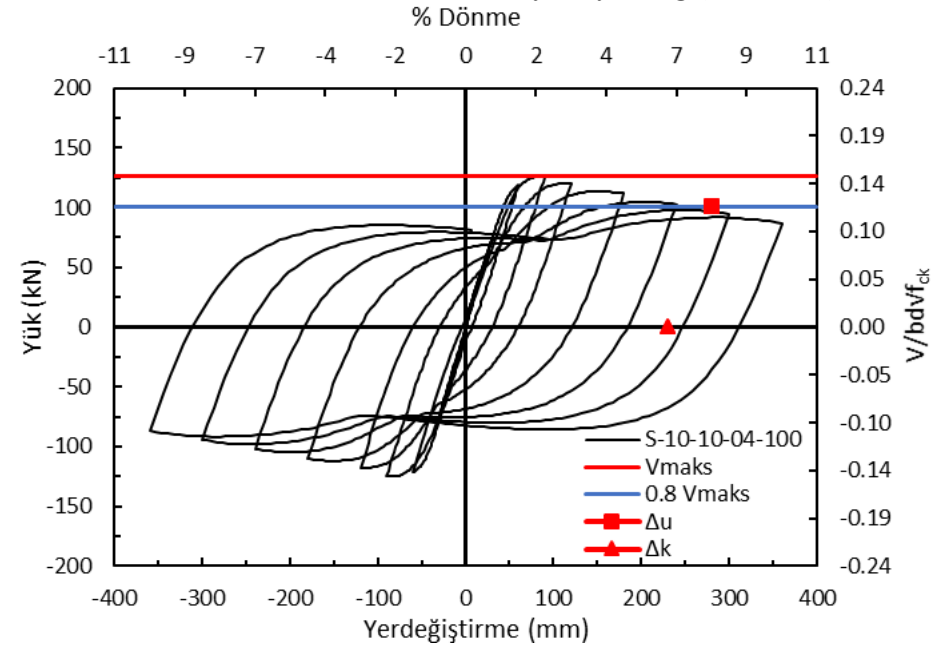

Şekil 12. S10-10-04-100 kolonuna ait yük-yerdeğiştirme ilişkisi 


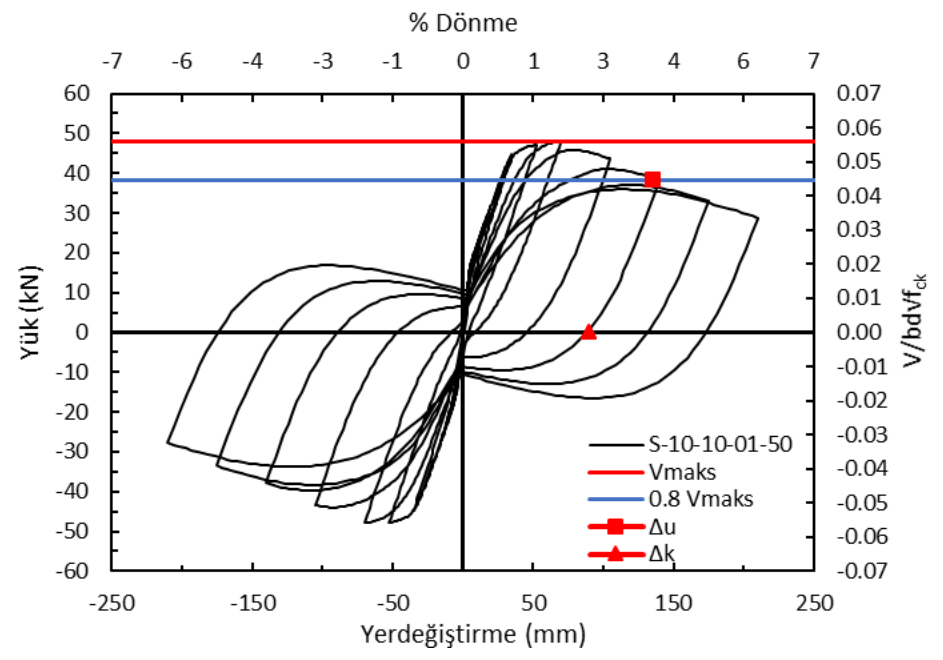

Şekil 13. S10-10-01-50 kolonuna ait yük-yerdeğiştirme ilişkisi

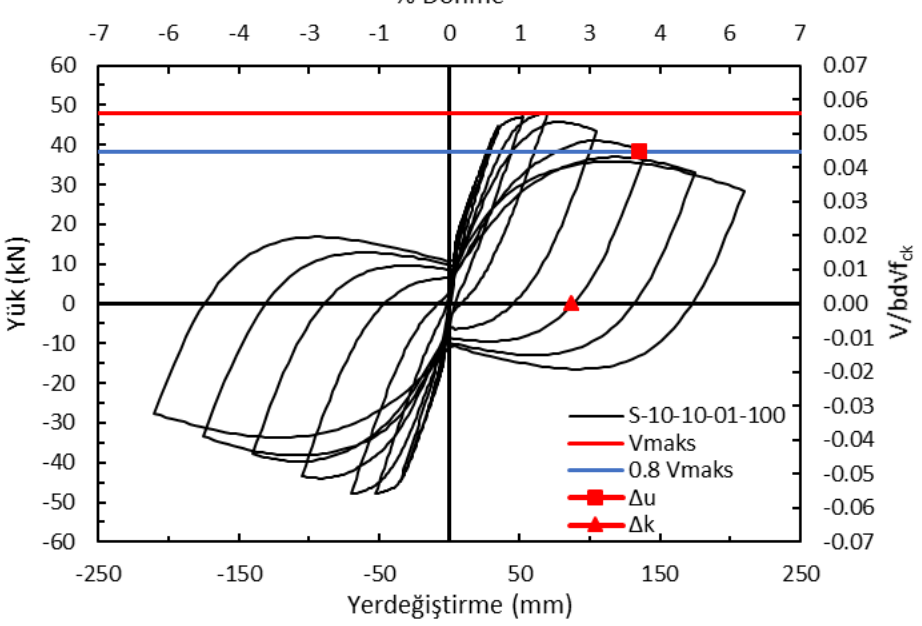

Şekil 14. S10-10-01-100 kolonuna ait yük-yerdeğiştirme ilişsisi

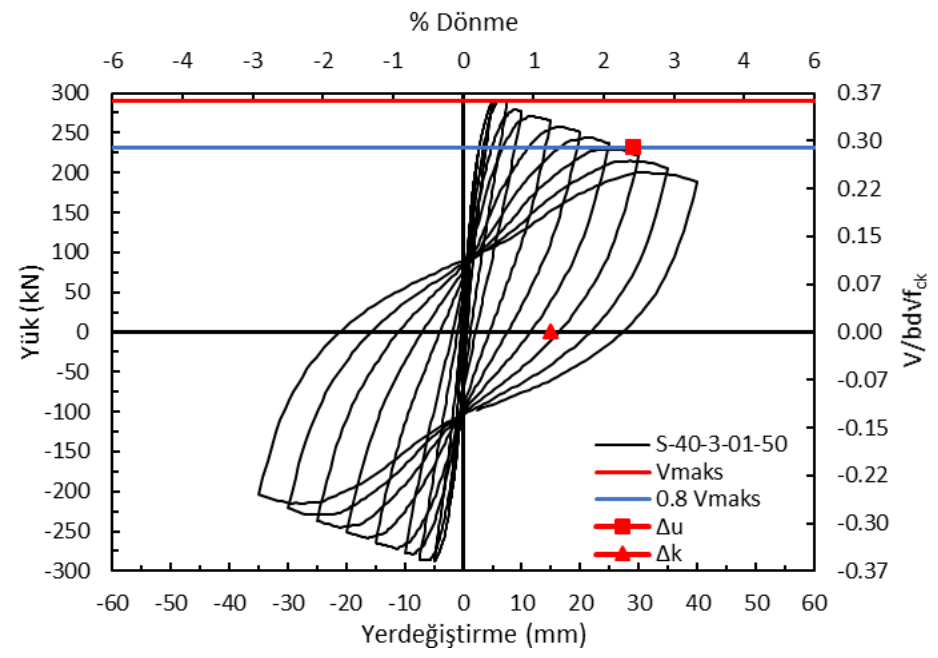

Şekil 15. S40-3-01-50 kolonuna ait yük-yerdeğiştirme ilişkisi 


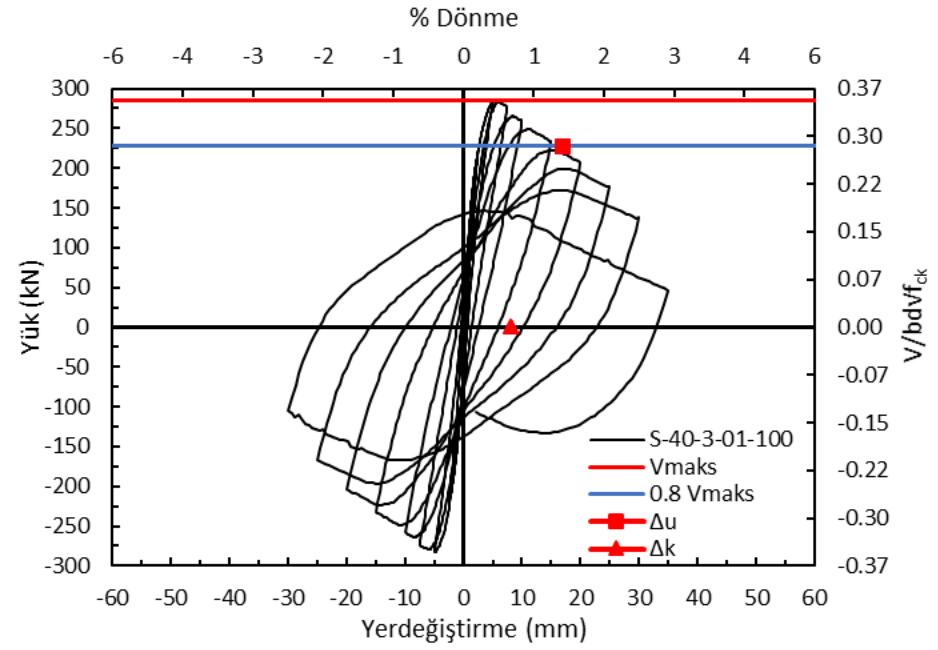

Şekil 16. S40-3-01-100 kolonuna ait yük-yerdeğiş̧tirme ilişkisi

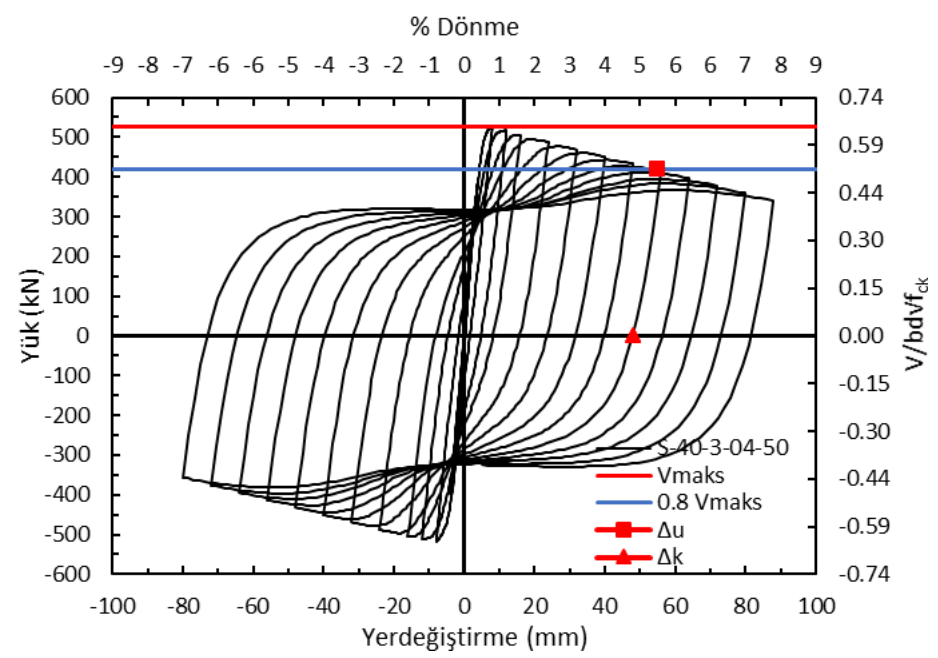

Şekil 17. S40-3-04-50 kolonuna ait yük-yerdeğiştirme ilişkisi

$\%$ Dönme

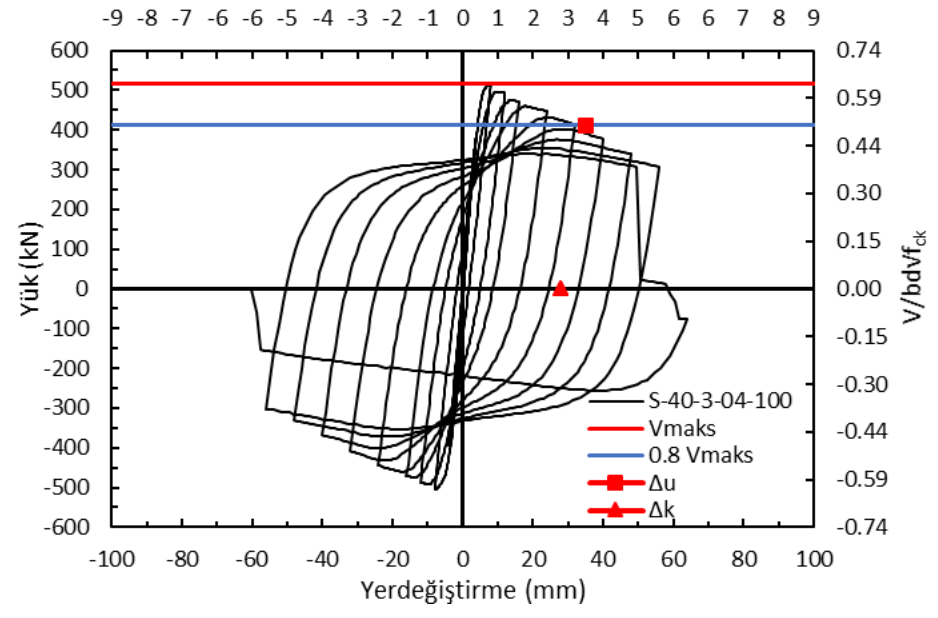

Şekil 18. S40-3-04-100 kolonuna ait yük-yerdeğiştirme ilişkisi 


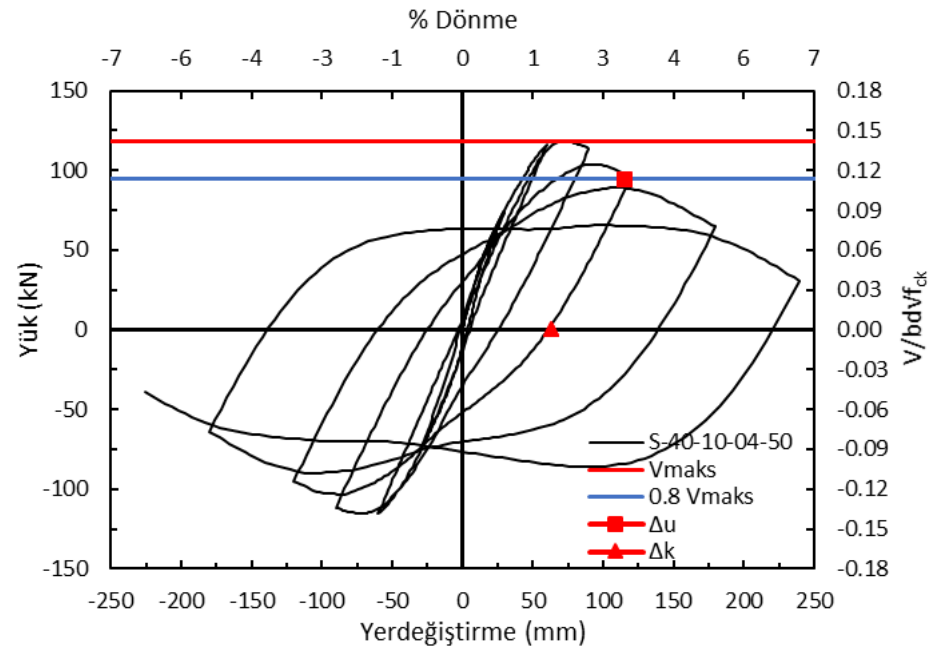

Şekil 19. S40-10-04-50 kolonuna ait yük-yerdeğiştirme ilişkisi

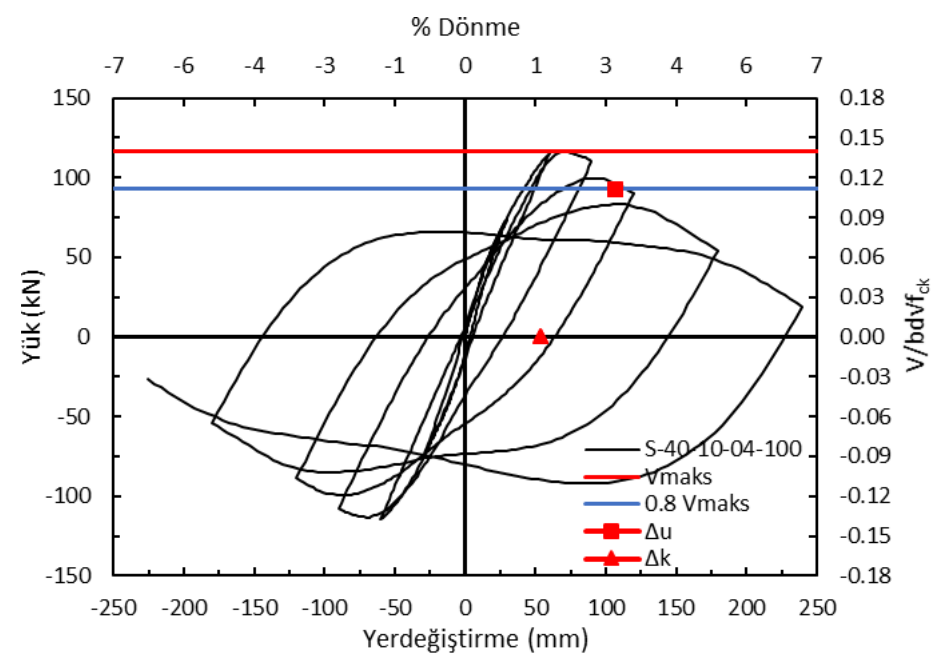

Şekil 20. S40-10-04-100 kolonuna ait yük-yerdeğiştirme ilişkisi

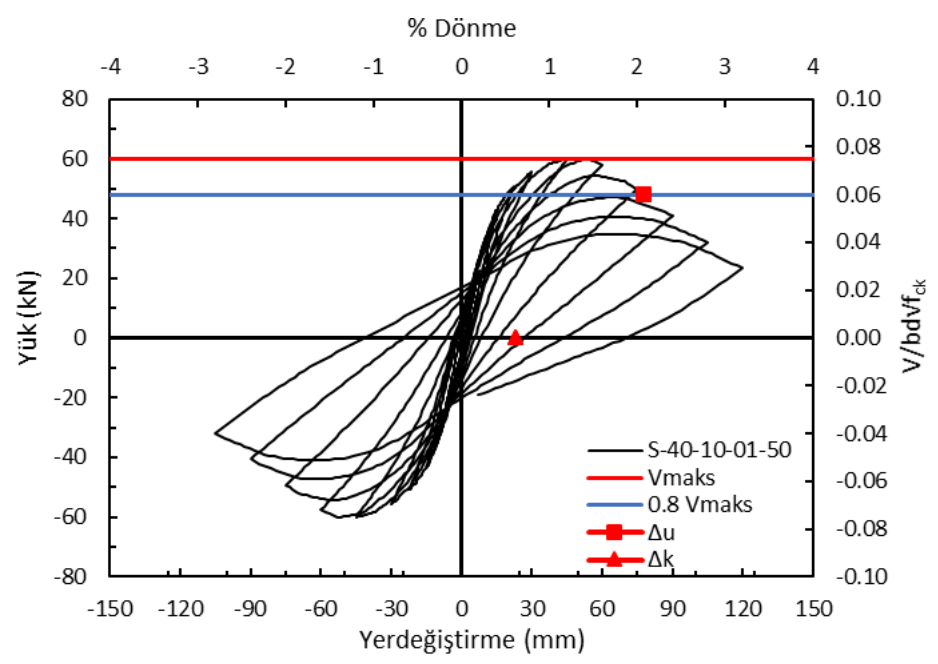

Şekil 21. S40-10-01-50 kolonuna ait yük-yerdeğiştirme ilişkisi 


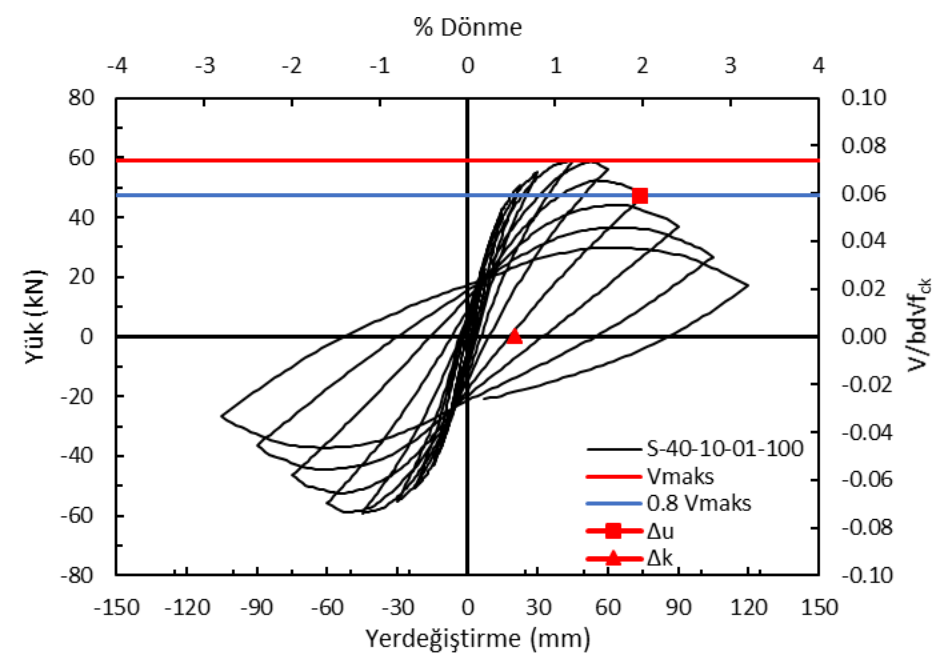

Şekil 22. S40-10-01-100 kolonuna ait yük-yerdeğiştirme iliş̧isi

\section{Değerlendirme ve Tartışma}

Dünyadaki birçok uluslararası ve ulusal deprem yönetmelikleri betonarme elemanların performansını belirli parametrelere göre hesaplamaktadır. Bu yönetmeliklerin ortak yönlerinden birisi ortalama olarak yatay yük taşıma kapasitesinde yaklaşı $\% 20-30$ arasında azalma meydana getiren yerdeğiştirme değeri kapasite olarak tanımlanmaktadır. Bu amaçla bu çalışmada sismik analizi yapılan 16 betonarme kolonun yatay yük taşıma kapasitesinde \%20 azalma meydana getiren yer değiş̧irme Şekil 8-23'de kırmızı ile gösterilen doğru olarak işaretlenmiştir.

Betonarme yapıların deprem sonrası hasarın göstergesi olarak taşıyıcı elemanlarda meydana gelen kalıcı yerdeğiştirme değeri güvenli bir veri olarak değerlendirilebilir. Deprem sonrası yapılarda oluşan hasarlara bakarak elemanın veya yapının performansını pratik olarak belirlemek birçok yapının hızlı değerlendirilmesi olanağını sağlayabilir. Bu amaçla kalıcı yerdeğiştirmeden elde edilen kalıcı dönme oranı betonarme kolonlarda performansın tayininde birçok yönetmelikte kullanılmaktadır. Bu bağlamda analitik modellenen kolonların sismik analiz sonucunda belirlenen kapasite değerleri Tablo 5'de gösterilmektedir.

Tablo 5. Kolonlara ait maksimum yerdeğiştirme kapasitesi altında meydana gelen kalıcı dönme oranları

\begin{tabular}{ccccc}
\hline Kolon Adi & $\begin{array}{c}\boldsymbol{\Delta}_{\mathbf{u}} \\
(\mathbf{m m})\end{array}$ & $\begin{array}{c}\boldsymbol{\Delta}_{\mathbf{k}} \\
(\mathbf{m m})\end{array}$ & $\boldsymbol{\theta}_{\mathbf{u}}$ & $\boldsymbol{\theta}_{\mathbf{k}}$ \\
\hline S-10-3-01-50 & 87 & 78 & 0.081 & 0.072 \\
S-10-3-01-100 & 77 & 70 & 0.071 & 0.065 \\
S-10-3-04-50 & 110 & 100 & 0.102 & 0.093 \\
S-10-3-04-100 & 122 & 115 & 0.113 & 0.106 \\
S-10-10-04-50 & 300 & 250 & 0.083 & 0.069 \\
S-10-10-04-100 & 280 & 230 & 0.078 & 0.064 \\
S-10-10-01-50 & 135 & 90 & 0.038 & 0.025 \\
S-10-10-01-100 & 135 & 87 & 0.038 & 0.024 \\
S-40-3-01-50 & 29 & 15 & 0.027 & 0.014 \\
S-40-3-01-100 & 17 & 8 & 0.016 & 0.007 \\
S-40-3-04-50 & 55 & 48 & 0.051 & 0.044 \\
S-40-3-04-100 & 35 & 28 & 0.032 & 0.026 \\
S-40-10-04-50 & 115 & 63 & 0.032 & 0.018 \\
S-40-10-04-100 & 107 & 54 & 0.030 & 0.015 \\
S-40-10-01-50 & 78 & 23 & 0.022 & 0.006 \\
S-40-10-01-100 & 74 & 20 & 0.021 & 0.006 \\
\hline
\end{tabular}


Tablo 4'te verilen dönme oranları 1 ve 2 denkleminden elde edilmiştir.

$$
\begin{aligned}
& \theta_{u}=\frac{\Delta_{u}}{L} \\
& \theta_{k}=\frac{\delta_{k}}{L}
\end{aligned}
$$

Tablo 4 irdelendiğinde elde edilen sonuçlar maddeler halinde sıralanmıştır.

- Yanal donatı oranı yüksek kolonlarda maksimum yerdeğiştirme altında daha fazla kalıcı yerdeğiştirme oluşmaktadır. Plastik dönme kapasitesi daha fazla olmaktadır.

- Boyuna donatı yüzdesi yüksek kolonların boyuna donatı yüzdesi düşük kolonlara göre yerdeğiştirme kapasitesi yüksek olduğu gibi kalıcı dönme oranları da yüksek olmaktadır.

- Kesme açıklığı yüksek kolonların kesme açıklığı düşük kolonlara göre yerdeğiştirme kapasitesi daha yüksek olmasına rağmen kalıcı dönme oranı daha düşük olmaktadır.

- Eksenel yük seviyesi kalıcı dönme oranını ve yerdeğiştirme kapasitesini en çok etkileyen parametre olarak öne çıkmaktadır.

Bu çalışmada kullanılan araştırma parametrelerinin kalıcı dönme oranlarını değiştirme yüzdeleri Tablo 6'da verilmiştir.

Tablo 6. Tasarım parametreleri ile kalıcı dönme oranı arasındaki ilişki

\begin{tabular}{lllll}
\hline & & \multicolumn{3}{c}{$\boldsymbol{\theta k}$ Etki yüzdesi aralı̆̆ } \\
\cline { 3 - 5 } Parametre & Artış & $\begin{array}{l}\text { En az } \\
\text { \% }\end{array}$ & $\begin{array}{l}\text { En } \\
\text { cok } \\
\text { \%o }\end{array}$ & $\begin{array}{l}\text { Ort. } \\
\text { \% }\end{array}$ \\
\hline Eksenel yük seviyesi $\left(\mathrm{N} / \mathrm{A}_{\mathrm{c}} \mathrm{f}_{\mathrm{ck}}\right)$ & & -148 & -650 & -355 \\
a/d oranı & $4 \mathrm{~kat}$ & -192 & -98 \\
Boyuna donatı yüzdesi $\left(\rho_{\mathrm{t}}\right)$ & $3.33 \mathrm{~kat}$ & -46 & -136 & 139 \\
Enine donatı yüzdesi $\left(\rho_{\mathrm{h}}\right)$ & $4 \mathrm{~kat}$ & 26 & 236 & 21 \\
\hline
\end{tabular}

Kalıcı dönme oranına etki eden en önemli parametrenin eksenel yük seviyesi olduğu, en az etki eden parametrenin ise enine donatı yüzdesi olarak öne çıkmaktadır. Elde edilen sonuçlar Statistica V10 programı üzerinde analiz edildiğinde parametreler arasındaki korelasyon ilişkisi bu durumu doğrulamaktadır. Analitik sonuçlara göre Statistica programı üzerinden kalıcı dönme oranının tahmini üzerine bağıntı üretildiğinde \%98 korelasyon ile doğru sonuç verdiği görülmüştür. Programdan elde edilen bağıntı 3 numaralı denklemde verilmiştir.

$$
\theta_{k, t a h .}=0.013\left(\frac{N}{A_{c} f_{c k}}\right)^{-1.05}\left(\frac{a}{d}\right)^{-0.93}+\rho_{t}\left(\rho_{h}^{0.24}\right)\left(\frac{N}{A_{c} f_{c k}}\right)^{-0.63}
$$

Betonarme kolonların yerdeğiştirme kapasitesini birçok sismik yönetmelikte farklı bağıntılar ile hesaplamaktadır. Bu çalışma kapsamında öncelikle betonarme kolonların yerdeğiştirme kapasitesine etki eden parametrelerin etki yüzdesi hesaplanmıştır. Hesaplanan etki yüzdeleri Tablo 7'de sunulmaktadır.

Tablo 7. Tasarım parametreleri ile yerdeğiştirme kapasitesi arasındaki ilişki

\begin{tabular}{ccccc}
\hline & & \multicolumn{3}{c}{$\theta$ Etki yüzdesi aralığ } \\
\cline { 3 - 5 } Parametre & Artış & $\begin{array}{c}\text { En az } \\
\%\end{array}$ & $\begin{array}{c}\text { En } \\
\text { çok } \\
\%\end{array}$ & $\begin{array}{c}\text { Ort. } \\
\%\end{array}$ \\
\hline Eksenel yük seviyesi $\left(\mathrm{N} / \mathrm{A}_{\mathrm{c}} \mathrm{f}_{\mathrm{ck}}\right)$ & $4 \mathrm{~kat}$ & -72 & -253 & -160 \\
a/d oranı & $3.33 \mathrm{~kat}$ & -6 & -168 & -58 \\
Boyuna donatı yüzdesi $\left(\rho_{\mathrm{t}}\right)$ & $4 \mathrm{~kat}$ & 25 & 118 & 72 \\
Enine donatı yüzdesi $\left(\rho_{\mathrm{h}}\right)$ & $2 \mathrm{~kat}$ & 2 & 40 & 15 \\
\hline
\end{tabular}

Birçok sismik tasarım yönetmeliklerinde izin verilen değer aralığında imal edilmiş betonarme kolonların yerdeğiştirme kapasitesini tahmini için istatistik programı yardımı ile analizi yapılmıştır. Bu doğrultuda en yakın sonucu veren bağıntı 4 numaralı denklemde sunulmaktadir.

$$
\theta_{k, \text { tah. }}=0.014\left(\frac{N}{A_{c} f_{c k}}\right)^{-0.91}\left(\frac{a}{d}\right)^{-0.60}+\rho_{t}\left(\rho_{h}^{0.16}\right)\left(\frac{N}{A_{c} f_{c k}}\right)^{-0.48}
$$

Analitik olarak hesaplanmış kapasite değerleri ile çalışmada önerilen 3 ve 4 numaralı denklemlerde tahmin edilen kapasite değerleri Şekil 23-24'de karşılaştırılmıştır. 


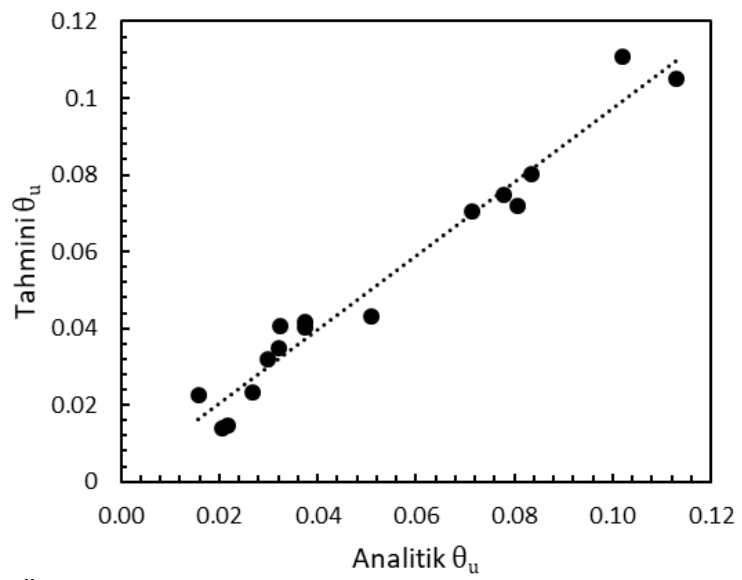

Şekil 23. Önerilen denklem ile analitik sonuçların karşılaştırılması $\left(\theta_{\mathrm{u}}\right)$

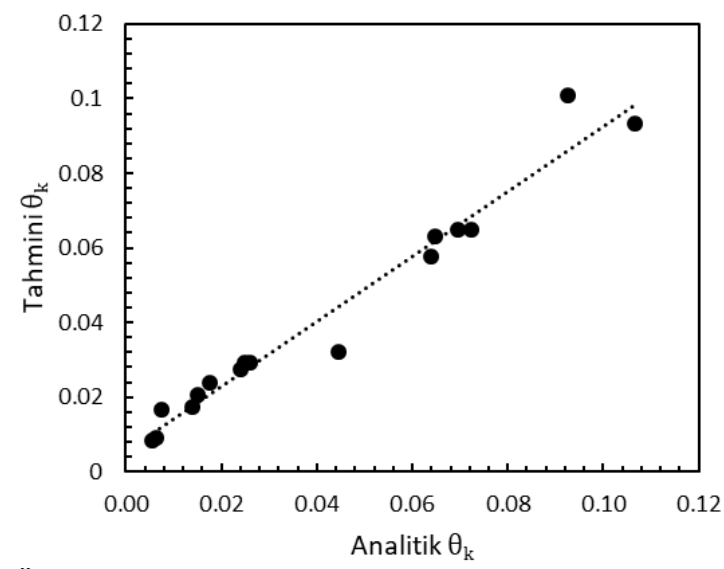

Şekil 24. Önerilen denklem ile analitik sonuçların karşılaştırılması $\left(\theta_{\mathrm{k}}\right)$

Sonuçlar incelendiğinde her iki bağıntının da analitik sonuçları düzgün tahmin ettiği görülmektedir. İlave olarak çalışmada önerilen bağıntıların doğrulanması amacıyla literatürde kullanılan rastgele seçilmiş ve farklı özelliklere sahip 6 betonarme kolon üzerinde deneysel sonuçlar ile karşılaştırılmıştır. Deneysel sonuçların karşılaştırılması Şekil 25-30'da gösterilmektedir. Deneysel verisi kullanılan kolonların özellikleri Tablo 8'de sunulmuş̧ur.

Tablo 8. Deneysel kolonlara ait özellikler

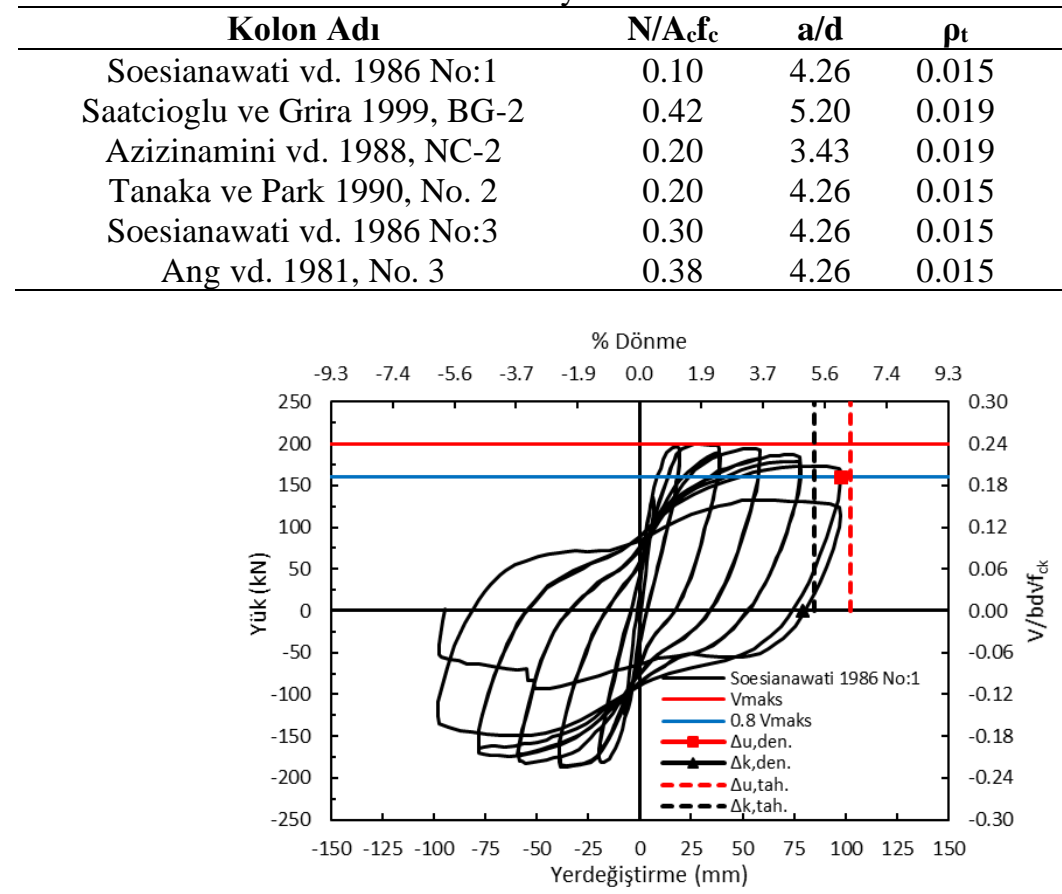

Şekil 25. Soesianawati vd. 1986 No:1 kolonu için deneysel sonuçlar ve önerilen bağıntının karşılaştırılması 
Deneysel sonuçlar ve önerilen bağıntının sonuçları incelendiğinde Soesianawati vd. 1986 No:1 kolonunda çok yakın tahminde bulunduğu görülmektedir. Özellikle yerdeğiştirme kapasitesi ile yerdeğiştirme kapasitesi altında oluşan kalıcı dönme oranını yaklaşık $\% 5$ daha fazla hesaplayarak tahmin etmiştir.

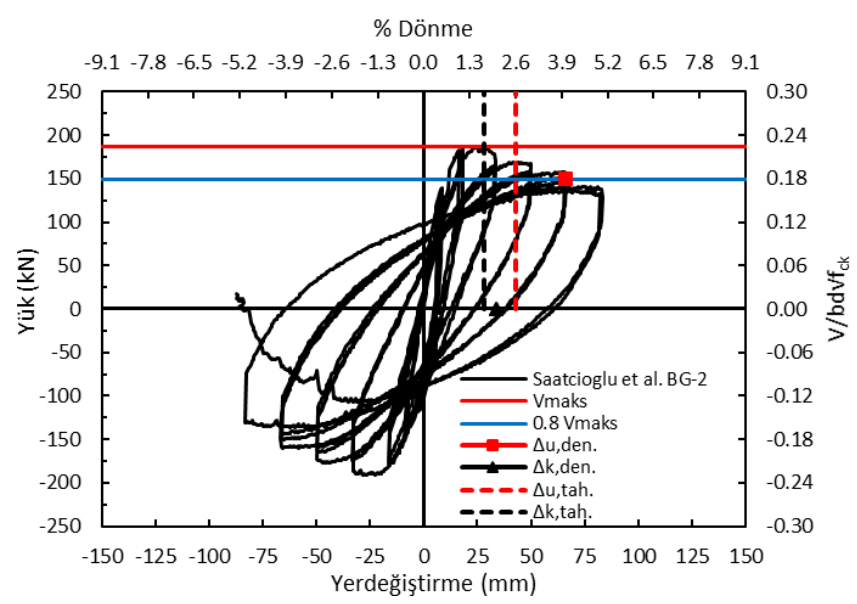

Şekil 26. Saatcioglu ve Grira 1999, BG-2 kolonu için deneysel sonuçlar ve önerilen bağıntının karşılaştırılması

Boyutsuz eksenel yük seviyesi 0.42 olan Saatçioğlu ve Grira BG-2 kolonu için kapasiteyi ihtiyatlı kalarak düşük tahmin etmektedir. Yönetmeliklerce izin verilen en yüksek eksenel yük seviyesi değerine sahip olması sebebiyle önem arz etmektedir.

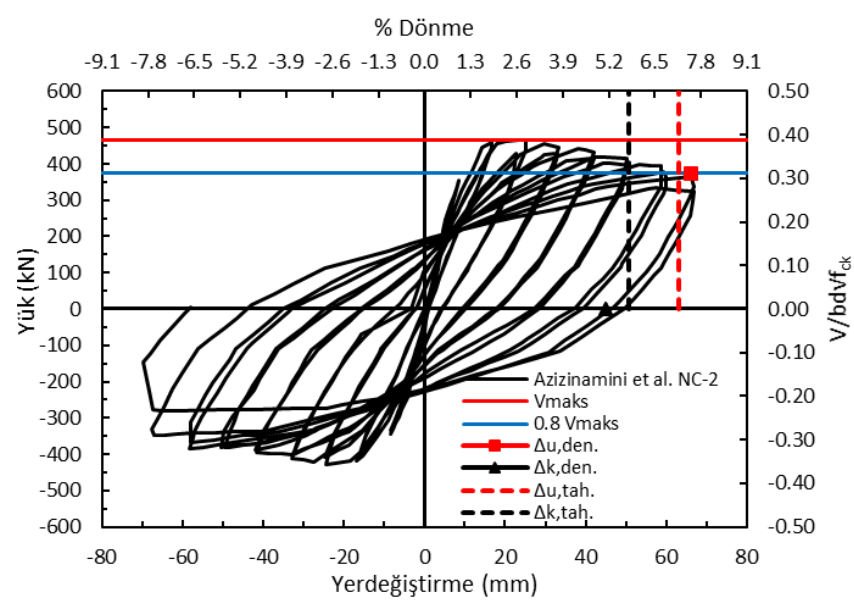

Şekil 27. Azizinamini vd. 1988, NC-2 kolonu için deneysel sonuçlar ve önerilen bağıntının karşılaştırılması

Orta seviye diye değerlendirilebilecek olan boyutsuz eksenel yük seviyesi 0.2 olan Azizinamini vd. 1988, NC-2 kolunu için ise kapasite değerleri ortalama \%8 bağıl hata ile tahmin edilmiştir.

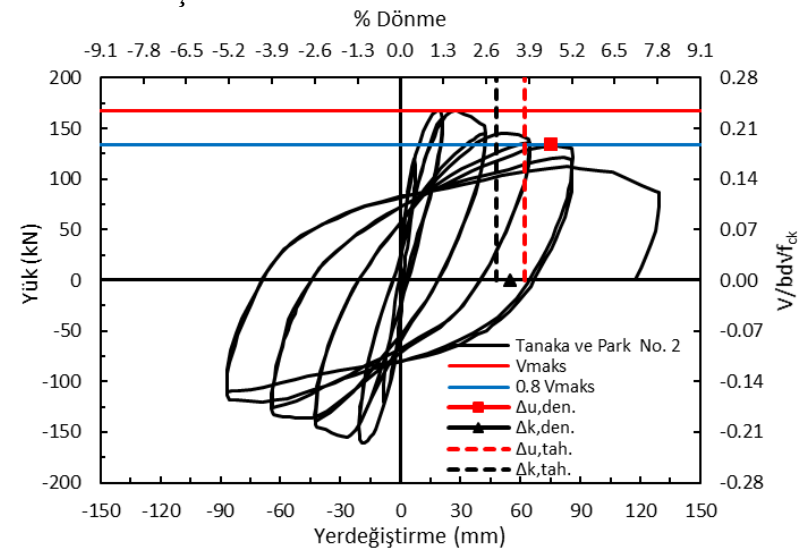

Şekil 28. Tanaka ve Park 1990, No. 2 [15] kolonu için deneysel sonuçlar ve önerilen bağıntının karşılaştırılması

Benzer özelliklere sahip Tanaka ve Park No:2 kolonu için çalışmada önerilen iki bağıntınında kapasite değerlerini yaklaşık \%13 bağıl hata ile hesaplamaktadır. Benzer şekilde sismik tasarım yönetmeliklerinde sıklıkla kullanılan eksenel yük seviyesinde oldukça iyi sonuç vermiştir. 
\% Dönme

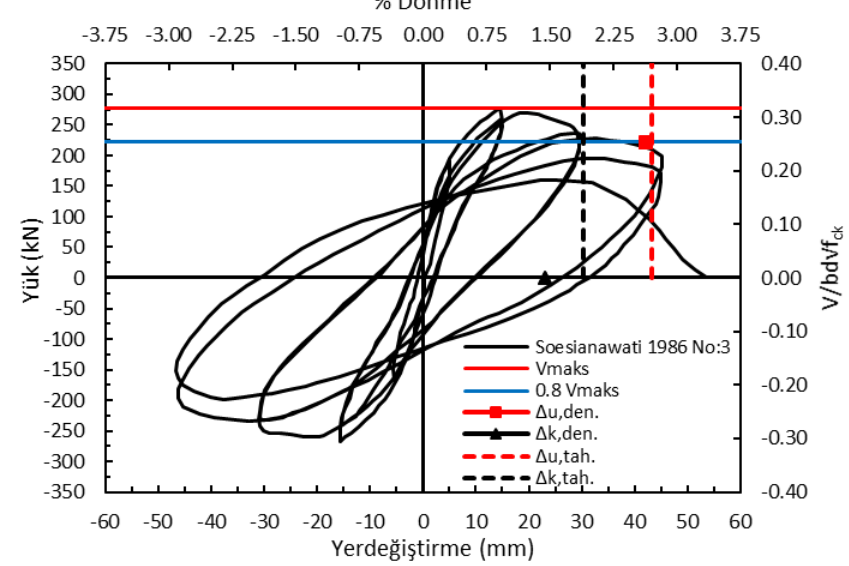

Şekil 29. Soesianawati vd. 1986 No:3 kolonu için deneysel sonuçlar ve önerilen bağıntının karşılaştırılması

Boyutsuz eksenel yük seviyesi 0.3 olan Soesianawati vd. 1986 No:3 kolonu için yerdeğiştirme kapasitesi yaklaşı olarak hatasız hesaplanırken, kalıcı dönme oranını veren bağıntı yaklaşık \%25 oranında fazla tahmin etmiştir.

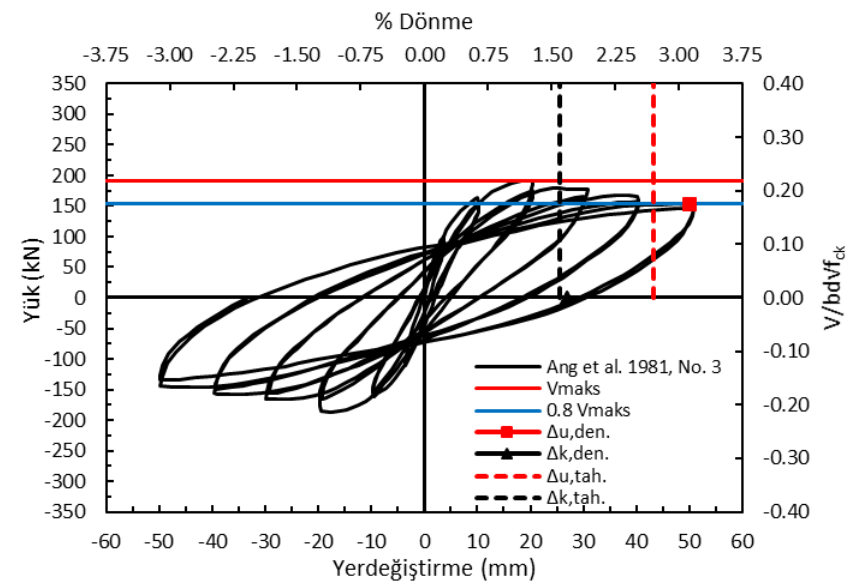

Şekil 30. Ang vd. 1981, No. 3 kolonu için deneysel sonuçlar ve önerilen bağıntının karşılaştırılması

Sismik yönetmeliklerde izin verilebilen maksimum boyutsuz eksenel yük seviyesine denk gelen Ang vd. No:3 kolonu için ise yerdeğiştirme kapasitesini tahmin eden bağıntı yaklaşık olarak \%8 bağıl hata ile hesaplamaktadır. Ancak kalıcı dönme oranı ise yaklaşık hatasız hesaplanmaktadır.

\section{Sonuçlar}

$\mathrm{Bu}$ çalışma kapsamında betonarme kolonun sismik yükler altındaki davranışına etki eden parametreler incelenmiştir. Literatürdeki önceki çalışmalar incelendiğinde farklı beton dayanımı, farklı enine donatı oranı, farklı boyuna donatı oranı, farklı en kesit alanı, farklı eksenel yük yüzdesi gibi değişkenler altında kısım kısım incelemeler yapılmıştır. Bazı araştırmacılar enine donatı etkisine yoğunlaşırken, bazıları da eksenel yük seviyesini detaylıca incelemiştir. Bu çalışmada ise betonarme kolon tasarımına etki eden temel parametrelerin yönetmeliklerce sınır kabul edilen minimum ve maksimum değerleri aralığında yatay yükler altında davranışı incelenmiştir. Bu açıdan birçok parametre sabit bir malzeme modeli ve malzeme dayanımı altında incelenmesi, parametrelerin etkisini daha tarafsız bir şekilde ortaya çıkarmaktadır.

$\mathrm{Bu}$ çalışmada elde edilen sonuçlar maddeler halinde sıralanmıştır.

- Deneysel yük-yerdeğiştirme eğrisi üzerine Seismo-Struct programından elde edilen analitik yerdeğiştirme eğrisi çizdirildiğinde, sonuçların çok yakın olduğu görülmüş̧ür. Seismo-Struct programının gerçek malzeme davranışını yansıtabilmesi sebebiyle deneysel sonuçlara çok yakın değerler verdiği tespit edilmiştir. Bu açıdan programdan elde edilen sonuçlar gerçek davranışı yansıtması sebebiyle, birçok farklı parametrenin doğru bir şekilde incelenme imkanı sunmaktadır.

- Önceki deneysel çalışmalara kıyasla farklı parametrelerle farklı değişken aralığında araştırma yapılmıştır. Kullanılan analitik modelin deneysel veriler ile doğrulanması sebebiyle kolon davranışına etki eden birçok parametre sismik yönetmeliklerde izin verilen geniş spektrumda incelenmiştir. Bu açıdan çalışma literatüre katkı yapacak nitelikte olduğu düşünülmektedir.

- Geniş spektrumda incelenen farklı parametrelerin etkisini dikkate alarak önerilen bağıntılar deneysel sonuçlar ile karşılaştırıldığında eksenel yük seviyesi düşük kolonlarda kapasite tahminin çok yakın hesaplamaktadır. Ayrıca eksenel yük 
seviyesi yüksek kolonlarda ise bağıntılar ihtiyatlı kalarak beklenen performansı sağlamaktadır. Sismik yönetmeliklerde izin verilen eksenel yük aralığında iyi sonuçlar verdiği deneysel verilerle kanıtlanmıştır.

- $\quad \mathrm{Bu}$ çalışmada önerilen bağıntılar, sismik yönetmeliklerde önerilen kapasite bağıntılarına göre daha sade olması sebebiyle ileriki çalışmalara 1şık tutabilecektir.

\section{Referanslar}

ACI 318 (2011). Building code requirements for structural concrete and commentary, American Concrete Institute; Farmington Hills, MI, USA.

Ang BG, Priestley MJN, Park R. (1981). Ductility of Reinforced Bridge Piers Under Seismic Loading. Report 81-3, Department of Civil Engineering, University of Canterbury, Christchurch, New Zealand, February.

Aykaç, S , Aykaç, B , Böcek, M . (2014). Dikdörtgen Kesitli Betonarme Kolonların Yaklaşık Hesabı İçin Basit Bir Formül . International Journal of Engineering Research and Development , 6 (2) , 13-22 . DOI: 10.29137/umagd.346078

Azizinamini A, Johal, LS, Hanson NW, Musser DW, Corley WG. (1988). Effects of Transverse Reinforcement on Seismic Performance of Columns - A Partial Parametric Investigation. Project No. CR-9617, Construction Technology,

Bae, S., \& Bayrak, O. (2008). Plastic hinge length of reinforced concrete columns. ACI Structural Journal, 105(3), 290.

Berry M, Parrish M, Eberhard M, (2004). PEER structural performance database user's manual, Pacific Engineering Research Center, Univ. of California, Berkeley, CA, 38.

CEN (2003). Eurocode 8: Design of structures for earthquake resistant, Part 1. Comité Européen de Normalisation, Brussels.

Deprem Bölgelerinde Yapılacak Binalar Hakkında Yönetmelik DBYBHY (2007). Bayındırlık ve İskan Bakanlığı, Ankara.

El-Bahy, A., Kunnath, S. K., Stone, W. C., \& Taylor, A. W. (1999). Cumulative seismic damage of circular bridge columns: Benchmark and low-cycle fatigue tests. ACI Structural Journal, 96, 633-641.

Elwood, K. J., \& Moehle, J. P. (2005). Drift capacity of reinforced concrete columns with light transverse reinforcement. Earthquake Spectra, 21(1), 71-89.

FEMA-356. (2000). Prestandard and commentary for the seismic rehabilitation of buildings. Report No. FEMA-356, Federal Emergency Management Agency, Washington, D.C.

Foroughi, S , Yüksel, S . (2019). Betonarme Kolonların Şekil Değiştirme Esaslı Hasar Sınırlarının Araştırılması . International Journal of Engineering Research and Development , 11 (2), 584-601 . DOI: 10.29137/umagd.519208

Lehman, D. E. (2000). Seismic performance of well-confined concrete bridge columns.

Mander, J.B., Priestley, M.J.N., Park, R., 1988: Theoretical stress-strain model for confined concrete. Journal of the Structural Division. Vol. 114, no. 8, pp. 1804-1826.

M. Menegotto, P.E. Pinto (1973), Method of analysis for cyclically loaded reinforced concrete plane frames including changes in geometry and non-elastic behaviour of elements under combined normal force and bending, IABSE symposium of resistance and ultimate deformability of structures acted on by well-defined repeated loads, vol. 13, International Association of Bridge and Structural Engineering, Lisbon, Portugal. pp. 15-22

Meral, E . (2019). Betonarme Binalarda Kısa Kolon Etkilerinin Araştırılması . International Journal of Engineering Research and Development , 11 (2) , 515-527 . DOI: 10.29137/umagd.495192

Özturk, B. M. (2003). Seismic drift response of building structures in seismically active and near-fault regions.

Öztürk, B., (2007). Evaluation of Drift Demand on the Basis of Nonlinear Response of Building Structures Located at Seismically Active Regions . 4th Conference on Earthquake Geotechnical Engineering, Selanik

Saatcioglu M and Grira M. (1999). Confinement of Reinforced Concrete Columns with Welded Reinforcement Grids. ACI Structural Journal, 96(1), 29-39. 
SeismoSoft, S. (2020). A computer program for static and dynamic nonlinear analysis of framed structures. Disponível online em: http://www. seismosoft. com.

Soesianawati MT, Park R, Priestley MJN. (1986). Limited Ductility Design of Reinforced Concrete Columns," Report 86-10, Department of Civil Engineering, University of Canterbury, Christchurch, New Zealand, 208 pages.

Tanaka H, Park R. (1990). Effect of Lateral Confining Reinforcement on the Ductile Behavior of Reinforced Concrete Columns. Report 90-2, Department of Civil Engineering, University of Canterbury.

Türkiye Bina Deprem Yönetmeliği TBDY (2018). Çevre ve Şehircilik Bakanlığı, Ankara.

TS 500, Betonarme Yapıların Tasarım ve Yapım Kuralları (ICS 91.080.40), Türk Standardları Enstitüsü, Ankara, 2000. 